REGARDS

SUR L'ECONOMIE ALLEMANDE

BULLETIN ECONOMIQUE DU CIRAC

\section{Regards sur l'économie allemande}

Bulletin économique du CIRAC

$84 \mid 2007$

Varia

\title{
Gouvernance territoriale
}

BLANKART Charles B., Föderalismus in Deutschland und Europa / FAURE Alain, LERESCHE Jean-Philippe, et al. (dir), Action publique et changements d'échelles : les nouvelles focales du politique / VOELZKOW et al., Die Governance regionaler Wirtschaftscluster. International vergleichende Analysen

\section{OpenEdition}

\section{Journals}

Édition électronique

URL : http://journals.openedition.org/rea/419

DOI : $10.4000 /$ rea. 419

ISBN : 978-2-8218-0864-5

ISSN : 1965-0787

Éditeur

CIRAC

Édition imprimée

Date de publication : 1 décembre 2007

ISSN : 1156-8992

Référence électronique

"Gouvernance territoriale », Regards sur l'économie allemande [En ligne], 84 | décembre 2007,

document 4, mis en ligne le 22 avril 2008, consulté le 22 septembre 2020. URL : http://

journals.openedition.org/rea/419; DOI : https://doi.org/10.4000/rea.419

Ce document a été généré automatiquement le 22 septembre 2020.

(c) CIRAC 


\section{Gouvernance territoriale}

BLANKART Charles B., Föderalismus in Deutschland und Europa / FAURE Alain, LERESCHE Jean-Philippe, et al. (dir), Action publique et changements d'échelles : les nouvelles focales du politique / VOELZKOW et al., Die Governance regionaler Wirtschaftscluster. International vergleichende Analysen

\section{RÉFÉRENCE}

BLANKART Charles B., Föderalismus in Deutschland und Europa, Coll. Neue Studien zur Politischen Ökonomie, Nomos Verlag, Baden-Baden, 2007, 218 p.

FAURE Alain, LERESCHE Jean-Philippe, et al. (dir), Action publique et changements

d'échelles : les nouvelles focales du politique, Coll. Logiques politiques, L'Harmattan, Paris, 2007, $378 \mathrm{p}$.

VOELZKOW et al., Die Governance regionaler Wirtschaftscluster. International vergleichende Analysen, Metropolis-Verlag, Marburg, 2007, 212 p.

1 On commence à s'interroger, en France aussi, sur une reconfiguration de l'articulation entre les différents échelons territoriaux de gouvernance, rendue nécessaire par l'accélération de l'intégration européenne (FAURE et al.). En Allemagne, où le fédéralisme a longtemps permis une bénéfique concurrence des modèles, la question est moins de savoir quels peuvent être les collectivités (Länder, communes ...) en charge de l'action publique que de restituer à chacune une partie des pouvoirs et ressources qui s'étaient dilués au fil d'une dérive trop égalitariste du fédéralisme. Sa réforme en est d'autant plus urgente que son architecture est aujourd'hui en porte-àfaux avec les processus décisionnels européens (BLANKART). Et que s'observe la montée en puissance de pôles de compétitivité dont la gouvernance n'obéit plus seulement à des règles nationales (VOELZKOW), comme le révèlent les clusters de biotechnologies (Munich et Cambridge), de production cinématographique et audiovisuelle (Cologne et Londres) ou automobile (Zwickau, Györ). (ib) 